\title{
WHY SHOULD LOCAL GOVERNMENTS HAVE A DEVELOPED COMMUNICATION STRATEGY? AN ANALYSIS OF MUNICIPAL COMMUNICATION IN THE CZECH REPUBLIC
}

\author{
${ }^{\mathrm{a}}$ MIROSLAV JURÁSEK, ${ }^{\mathrm{b}}$ PETR WAWROSZ \\ University of Finance and Administration, Estonská 500, \\ Prague, Czech Republic \\ email: ${ }^{a}$ jurasek.miroslav@mail.vsfs.cz, \\ bwawrosz.petr@mail.vsfs.cz
}

Acknowledgments: The result was created in solving the student project No. 7427/2020/06 "Intercultural communication: the research on the concept of cultural intelligence (CQ)" using objective oriented support for specific university research of the University of Finance and Administration". The article further uses data from the project „Implementation unit of the Strategic Framework for the Development of project "Implementation unit of the Strategic Framework for the Development of Public Administration of the Czech Republic for the period 2014 - 2020“ (,Implementačni jednotka Strategického rámce rozvoje verejné správy Ceské republiky pro období $2014-2020$ ), reg. no. CZ.03.4.74/0.0/0.0/15_019/0000125, that is financed from the European Social Fut. Our special thanks go to the Department of Strategic Development and Coordination of Public Administration of the Ministry of the Int the Department, and Mr. F. Zavrel. The former gave his kind consent to analyze the raw data collected by employees of the Department, the latter contributed significantly to the descriptive statistical analysis of the data and consulted the analytical process with the authors of the study. Abstract: The creation of a communication strategy is an indicator of the subject's approach to communication wih the ppblic. The aticle, based on a sample of 160 municipalities of the Czech Republic, empirically demonstates that an elaborated communication strategy enhances the public value of intangible assets particularly in the following areas: various segments of citizens are better targeted through a greater number of frequented communication channels, municipal employees are more frequently trained in communication issues, crisis communication plans are likely to be prepared. On the other hand, we confirmed that all these factors are limited to some extent by the size of the municipality and the financial resources allocated for communication.

Keywords: communication strategy, municipalities in the Czech Republic, competitive advantage, intangible asset

\section{Introduction}

A number of studies (Kawa \& Anholcer, 2019; Khan \& Hasan, 2016; Radjenović \& Krstić, 2017) have shown that intangible assets are one of the key sources of competitive advantage for organizations. The possession of appropriate intangible assets (whether of an economic or social nature) affects directly the performance of organizations and gives companies a competitive advantage (Canel et al., 2020), although this is variable over time and always temporary (Kawa \& Anholcer, 2019).

Intangible assets have a positive impact on the productivity of organizations and companies, not only in the private but also in the public sector (Canel et al., 2020; Ocak \& Findik, 2019). In the public sector, these assets are associated with knowledge and human resources (as opposed to the private sector, where they are largely associated with profit), specifically intellectual and social capital, trust, and reputation (Flatt \& Kowalczyk, 2008; Canel \& García, 2013). The management of intangible assets in the public sector is less open to market competition (compared to the private sector); it is less concerned with cost reduction and consumer preference, more subject to public scrutiny, influenced by various constraints and, last but not least, affects a greater number of stakeholders. Canel et al. (2020) combined the two concepts of public value and intangible assets to create a new concept: the publicly valuable intangible asset. In this context, they focused their attention on another intangible asset (often neglected in the literature): communication. Some intangible assets are based on perception and therefore would not exist without communication. This is particularly true for the public sector, as public institutions manage public money and therefore have a duty to account publicly for their activities.

The seriousness of the approach to communication can be confirmed by creating a communication strategy. For cities and municipalities, a well-designed communication strategy has positive effects: it can help attract tourists and foreign investment to the municipality (city). Canel et al. (2020) pointed out that the gap between real and perceived performance may indeed indicate a communication problem. If communication is inadequate, then the intangible public value of the public sector organization is lost. On the other hand, well-designed communication based on communication strategy helps public sector organizations create intangible assets that have value to society.

In this study, a sample of 160 municipalities in the Czech Republic is used to examine communication strategy as an intangible asset that generates a specific public value (Bozeman \& Johnson, 2015). Our analysis is based on the assumption that the effectiveness rating of the communication depends on the quality of the relationships created between the municipality and citizens. Elected municipal officials choose from three approaches to communication: passive, pragmatic, and participatory (Ochrana et al., 2015). This study emphasizes the pragmatic approach to communication: public involvement in the municipality (city) is part of building its positive image; communication is used only selectively and is based on municipal/regional marketing tools; the citizen is perceived as a client.

The literature has not yet sufficiently explained how to monetize intangible assets (in our case identified with the municipal communication strategy) through certain behaviors of a selfgoverning municipality. It is not clear what this behavior should look like. Our study extends previous predominantly qualitative assessment (Msibi \& Penzhorn, 2010) of the importance of a communication strategy and illustrates (or explains) why it is good to have this strategic document thoroughly elaborated and written down. This is because it sends a clear signal to citizens that the municipality is proactive (not passive, merely fulfilling its legal duty to provide information), does not hesitate to spend money on communication (because it believes it will be socially worthwhile), and prefers a somewhat binding communication plan over intuitive management of its communication with citizens. This first step (i.e. the development of a written communication strategy) is crucial as it highlights, on a noncausal level, the many positive impacts of a proactive approach to communication.

The text of the study is organized as follows: the key concepts of this study are defined in literature review (chap. 2): the intangible asset generating public value and one of its forms communication, the media types (or communication channels) that municipalities have at their disposal to achieve their communication goals and to affect their media image; public administration and its classification in the Czech Republic are here also characterized. The third chapter formulates the hypotheses, illustrates the conceptual scheme of the research, and describes the survey (target population, sample design, measurement method). In the fourth chapter, the results of the statistical analysis are presented and discussed, including the interpretation of the regression model.

\section{Literature review \\ 2.1 Public administration as part of the public sector}

The definition of the public sector includes three important aspects related to economic development, control, and public purposes (Canel \& Luoma-aho, 2018; Canel et al., 2020). In this sense, the public sector is part of a state-controlled economy: it consists of institutions controlled by the state, it provides public services, it is under public (government) control. Last but not least, it includes all entities or human resources that were created and exist, or are employed, in the public interest (for public purposes). Public control (in the sense of the executive, legislative, and judicial exercise of public authority) takes place at local, regional, national, and international levels. Public organizations are distinguished from private organizations by the following features (Thoenig, 2006): they are collectively owned by members of the political community, they are largely funded 
by taxes (more than fees paid by customers), and they are controlled by political forces rather than the market (Liu \& Horsley, 2007).

The public sector is characterized by its values (production of collective goods, adherence to due process, democratic accountability) that permeate the activities of public sector employees. Public values become the output of their work and are something that society values, strives for, and achieves through public institutions (Canel et al., 2020).

The public sector includes public administration, which manages public affairs in the public interest. In the Czech Republic, it is divided into central public administration (with national scope, such as ministries and central administrative offices) and local public administration (territorial, i.e. municipalities and regions, and professional). Public administration is a hierarchically organized activity based on relationships of superiority and subordination; decisions are generally reviewed by a higher authority of the public administration for compliance with the law and with the internal acts of higher authorities. Elections are exceptional, the appointing principle prevails in the establishment of the authorities; the monocratic principle of decision-making is more often promoted. However, in selfgoverning units, there is no vertical hierarchy (no superior/subordinate relationship), decisions are taken autonomously, decisions taken are reviewable only for compliance with the law, the electoral principle prevails, and collective decision-making is common (Ochrana et al., 2015).

\subsection{Public sector marketing}

Kaplan \& Haenlein (2009) pointed out in their study the growing importance of public sector marketing, which can also (but with some differences and limitations compared to marketing for commercial firms) be applied to four basic marketing concepts: product, price, place, and promotion. Although the same rules apply to the marketing communication of cities or municipalities and commercial companies, different marketing tools cannot be used without careful consideration. Marketing principles known from the business sphere may not apply in the public space, as pointed out by Graham (1994). It is necessary to take into account the special nature of public services and their categorization (Laing, 2003). The core of the marketing of the territory (state, region, municipality) should be the institutionalized support of communication between the demand side (citizen, tourist, etc.) and the supply side - state, regional, municipal administration and the service providing organizations it has established or founded.

\subsection{Strategic communication as an intangible asset of public organizations}

Communication plays a key role in the provision of public services (Canel \& Luoma-aho, 2018; Canel et al., 2020). The provision and transmission of information to the public should be seen as a public service. Moreover, active communication enables a municipality to promote its own issues in public discourse. On the other hand, communication is not only a oneway flow of information; communication also involves the transfer of opinions and information from the public to the administration. Without taking into account the public's opinions and suggestions in decision-making processes, the decisions made be out of touch with the reality of practical life in the city.

No unified definition of strategic communication currently exists and it cannot be assumed that researchers will agree on one in the future (Thomas \& Stephens, 2015). Strategic communication tends to be defined (Hallahan et al., 2007) as the meaningful use of communication by organizations to achieve their stated missions and goals. It covers six areas: management, marketing, public relations, technical communication, political communication, and social communication/information campaigns. It is the meaningful use of communication to promote and develop the organization's raison d'etre. A communication strategy sets out the process by which the public and other key stakeholders will be informed about the ongoing activities of the city and how they can be involved in the process (Nielsen \& Salomonsen, 2012). The purpose is for the general public to understand the reasons and activities related to the city's governance and see the results achieved. Municipalities (cities) pursue several objectives with their communication strategies:

- Ensure that the public is informed in a timely, understandable and credible manner, including obtaining feedback in the form of citizens' opinions and suggestions (Hong et al., 2012);

- Increase citizen participation in the decision-making processes of the municipality (city) (Bonsón et al., 2019);

- Unify communication tools used for external (outside city hall) and internal (inside city hall) communication.

The communication strategy is usually prepared as a mediumterm strategic document; the measures for its implementation are often specified in annual communication plans, which are usually prepared for a period of one year and contain a brief list of communication topics, identifying the substantive and politically relevant issues. The implementation of these themes should be evaluated in a responsible analytical manner and the results of the evaluation should be reflected in the communication activities of the subsequent period.

Communication strategies are divided into internal and external. In terms of internal communication, it is primarily a matter of setting up appropriate communication channels, which are based on the Authority's organizational structure and information concept. External communication fulfills several functions in pursuit of the objectives of the communication strategy. This consists primarily of securing information flows between the municipality and the public in the broadest sense of the word. Secondarily, it is about creating a positive image of the municipality, both for its own residents and residents of the region as a whole, as well as visitors.

\subsection{Media image of municipalities}

Different types of media and sources of information are categorized based on the level of activity they require of the recipient, how much information the individual has to complete, and how many senses the media simultaneously affects. In this sense (according to the state of being filled with data), the Canadian philosopher and well-known mass media theorist Marshall McLuhan distinguished between hot and cold media (Starosielski, 2014). The media have a profound influence on the public's thinking and behavior; they are a means of engaging the public. It is true that the content of the media has a delayed effect on public attitudes and opinions (Ježek, 2010, 2011; Hoffman, 2013). The topics discussed in the media have a real impact on perceptions of the importance and relevance of these topics with a real impact on their behavior (Hitt \& Searles, 2018). According to a recent survey, $61 \%$ of Czechs trust the media (AMI Digital, 2021).

Municipalities create their media image in a number of areas such as investment activity, awareness of residents, environment including living environment, tourism. Municipal leaders can bring topics they consider important into the media space and reach out to residents. The basic tools for working with the media are: press conferences, press releases, interviews, press packs, websites, electronic and printed newsletters, lectures and seminars, informal meetings with journalists, press trips. There is also a need for as many people as possible to communicate on behalf of the municipality, as this creates a more credible impression. On the other hand, if too many people communicate, there is a risk of uncoordinated, contradictory statements. Last but not least, media monitoring (offline and online monitoring) should be carried out. A media analysis of the trends over time, media used, communicators, and topics shows the image of the municipality in the media, evaluates the success of press releases and conferences, assesses the media response to various topics, 
events, and actions, and calculates the impact of a crisis event on the media image of the municipality (Evstratova et al., 2020).

\section{Material and methods}

\subsection{Objectives and hypothesis}

We start from the premise that the systematic and conscious creation of intangible assets (in our case, a sophisticated communication strategy) creates public value. However, it is not enough to simply work for the public good; one must communicate the results of one's work/activity to the public and give them as much space as possible to actively participate and engage in the community. It is only through communication (or regular interaction) with stakeholders that intangible assets (such as credibility, social capital) can be created that will be of general benefit. If, through open communication, the needs and expectations of stakeholders are recognized, both intangible assets and public value will guide decision-making and help organizations improve their operations. Canel et al. (2020) argue that public value can only be created in a multi-sectoral and multi-level context that go beyond the capabilities of government, and that public value intangible assets are more effectively created through public-private partnerships. Communication can be effective only if it is made by officers and supported by heads of municipalities.

In line with the principles of social return on investment, we assume that the resources spent on the development of a communication strategy (which for the purpose of our research is understood as an intangible asset that brings some value to society) will pay off because public administration organizations (municipalities) will be more purposeful in the use of communication channels and in development of resources devoted for communication. Municipalities will have further developed a coherent idea how to implement their communication goals. We also assume that municipal communication, as an intangible asset creating a certain public value and also a certain competitive advantage, takes place in a certain environment and depends on contextual variables such as city size, budget, and location.

Figure 1. Conceptual framework

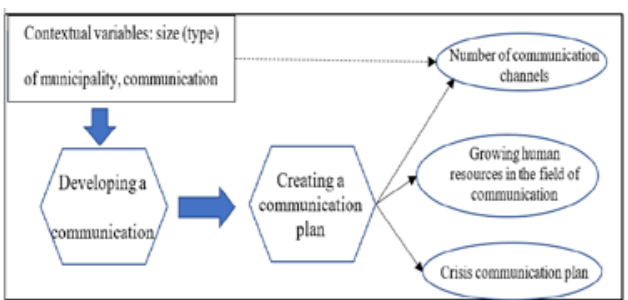

Source: own work

In a comparison of two groups, i.e. municipalities with a written communication strategy (=1st group) and municipalities without a written communication strategy (=2nd group), the following hypotheses are tested:

H1: Group 1 respondents use more communication channels than Group 2.

H2: Group 1 respondents are better prepared for crisis communication than Group 2.

H3: Municipalities with a communication plan take better care of human resource development in communication than municipalities without a communication plan.

Next in hypothesis 4, contextual variables are tested. H4: There is a positive relationship between the number of people involved in communication in government offices and the amount of financial resources allocated to the implementation of the communication strategy.
It is likely that the variety of the palette of communication tools or their variation will increase with the amount of funds that municipalities have allocated and budgeted for communicating with their citizens. It can also be assumed that municipalities that exercise not only autonomous but also increasingly delegated powers have more staff and financial resources at their disposal and are likely to use more communication channels to communicate with their citizens. To test the assumption that the type of municipality (Type I, II, or III) ${ }^{1}$ is related to the number of communication channels used, a multiple regression model was created with multiple independent variables including a municipality type variable with three categories: Type I, Type II, and Type III. The dependent variable is the number of communication channels used by the municipality. Since the size of the municipality is related to the type of municipality, the relationship between the number of inhabitants of the municipality and the number of communication channels used to reach them was tested using a multiple regression model. It can be intuitively assumed and suspected that the demographic structure of a municipality (city) becomes more complex as the size of the municipality, i.e. the number of its inhabitants, increases. Since different people prefer different communication channels (Nielsen \& Salomonsen, 2012), experienced communication specialists must take this fact into consideration and, as part of the adopted communication strategy, try to diversify communication channels as the population of the municipality grows.

It is clear (and will be shown empirically) that larger municipalities have better opportunities and conditions for communication than smaller municipalities. However, the size of municipalities and the extent of the entrusted powers they exercise are not the only criteria that determine the extent to which municipalities (cities) are communication proactive (this variable is operationalized by the number of communication channels a municipality uses to communicate with its citizens). A multiple regression analysis is used to examine whether there are statistically significant differences between regions in the use of different communication channels, which to some extent relativizes the "size" factor and shows that municipalities can also conduct quality communication regardless of their size.

\subsection{Data collection and sample}

The data for the analysis was collected by the Department of Strategic Development and Coordination of Public Administration of the Ministry of the Interior of the Czech Republic as part of the project "Implementation Unit of the Strategic Framework for the Development of Public Administration of the Czech Republic for the period 20142020". The questionnaire was distributed electronically. The questionnaire survey was conducted between February and March 2021. All municipalities with extended competence (205) were contacted via data mailboxes with a request to distribute it also to other municipalities (municipalities with an appointed municipal authority and municipalities with basic competence) in their administrative district. In addition, the municipal districts of the capital city of Prague (22), which have jurisdiction similar to municipalities with extended jurisdiction, were contacted in the same way. The electronic address of the questionnaire was also published on the website www.kvalitavs.cz.

The individual items of the questionnaire were inspired by the communication strategies of various towns such as Uherský Brod, Moravská Třebová, Palkovice, etc. Demographic questions that were recorded related to the type of municipality and number of inhabitants. It was determined whether the municipality employs (or) hires a graphic designer, whether it has a developed visual style of the municipality. Respondents were also asked about the size of the communications budget

\footnotetext{
${ }^{1}$ The article uses standard terminology: type I municipalities = all municipalities; type II municipalities = municipalities with a delegated municipal authority; type III municipalities = municipalities with extended jurisdiction. For details see e.g. Potěšil et al. (2019).
} 
and the number of full-time employees dedicated to communications at the town (city) hall. Responses were mostly dichotomous (binary, categorical: Yes $=1$, No $=0$ ). An example of the questions used is: "Does your government office have a written and currently valid communication strategy?"

In the dataset, a total of 160 responses (2.6\% of the total number of municipalities in the country, i.e. 6,254 ) were obtained, with the following proportions by type: 4 (18\% of the total number) city offices of Prague, 108 (1.8\% of the total number) municipalities with basic jurisdiction (type I municipalities), 9 (4.9\% of the total number) municipalities with an appointed municipal authority (type II municipalities) and 39 (19\% of the total number) municipalities with extended jurisdiction (type III municipalities). Municipalities in all regions of the Czech Republic were contacted. No response was received from the Karlovy Vary Region. The largest number of responses came from the Central Bohemia Region (31), the Moravian-Silesian Region (24), and the Vysočina Region (24). Larger municipalities were represented in the research sample in a higher proportion than small municipalities.

\section{Results and discussion}

The collected data was analyzed using IBM SPSS 19 software. The following communication channels are used by municipalities (numbers in parentheses indicate the weights or importance of each communication channel in the overall communication mix of municipalities: website (26\%), municipal newsletter (22\%), social networks (17\%), mobile radio application (12\%), email or SMS messages (14\%), video channel (6\%), electronic newsletter (3\%).

The vast majority of municipalities (89\%) do not have a written strategic communication document. On the other hand, a more detailed analysis suggests that this "intuitive" (non-intentional, non-systematic, non-sophisticated, non-considered) approach to communication is not desirable and municipalities are saving in the wrong place. While it cannot be argued that the written elaboration of a strategic communication concept stimulates municipalities to greater communication activity (causality induced by the "mere" elaboration of a document cannot be sought), it is nevertheless true that municipalities that invested time and resources in the elaboration of a communication strategy ( $n=30, M=5.47, S D=2.54$ ), use more communication channels (and are thus more active in communication) than municipalities that have not developed such a document $(\mathrm{n}=$ 130; $\mathrm{M}=3.8 ; \mathrm{SD}=1.99), \mathrm{t}(158)=3.24, \mathrm{p}<.01)$. The first hypothesis (H1) is thus confirmed. This can be explained by the fact that the preparation of the concept in written form (and thus the expenditure of funds and human resources on this activity) to some extent obliges and creates pressure to meet the set objectives, plan, and recommendations. The written formulation forces a certain amount of thought into the entire concept, and the costs involved are likely to lead to its implementation.

Tab. 1: Relationship between the development of a communication strategy and a crisis communication manual

\begin{tabular}{|c|c|c|c|c|}
\hline & & \multicolumn{3}{|c|}{ Strategy } \\
\hline & & Yes & No & Tota \\
\hline \multirow{3}{*}{ Plan } & YES & $16(52 \%)$ & $14(11 \%)$ & 30 \\
\hline & NO & $15(48 \%)$ & $115(89 \%)$ & 130 \\
\hline & Total & 31 & 129 & 160 \\
\hline
\end{tabular}

Source: own research

It is clear from tab. 1 that $52 \%$ of respondents (surveyed municipalities) that have developed (or had developed) a communication strategy also have a crisis communication plan, which is by $41 \%(52 \%-11 \%)$ more than municipalities that have not developed a strategic communication plan. The results of the analysis can be generalized from the sample to all municipalities, as shown by the chi-square test, $\chi^{\wedge} 2(1, \mathrm{n}=160)=$ 27.26, $\mathrm{p}<.01$. Municipalities with a developed communication strategy are more likely to be proactive in developing a binding (updated) action plan than municipalities without a written communication strategy. In other words, by developing a communication strategy of strategic importance and taking on a certain commitment subject to public scrutiny, the municipality is creating a basis for purposeful action in this area. It can be argued with relatively high probability that municipalities (almost half of them), having developed a communication strategy, also have a plan for crisis management. This relationship is quite significant (Cramer's $\mathrm{V}=.41$ ); the strategy and the plan are related. Hypothesis $\mathrm{H} 2$ is thus confirmed. On the other hand, the predictive relationship between the two nominal variables is not very strong (lambda $=.065$ ): the success rate of correctly predicting that municipalities with a developed communication strategy will also have a crisis management plan is quite low. The data analysis also showed that there is virtually no difference between whether municipalities prepare their own communication strategies or have them developed externally. As a rule, municipalities prefer to prepare plans either for a short period (1-2 years) or for a very long period (more than 5 years).

The plans implementing the communication strategy usually also take into account the development of human resources in the field of communication, as our data show a moderately strong relationship between the two nominal variables, i.e. the development of a communication plan and the training of employees in this direction (see Table 2). Hypothesis H3 is confirmed.

Tab. 2: Relationship between training and communication plan

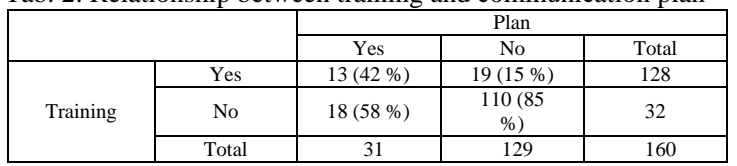

Source: own research

Although municipalities are far from having a communications department in their government offices (only in 19 cases, i.e. less than $12 \%$ ), the amount of resources that municipalities spend on communication is quite logically related to the amount of employees taking care of communication there, $\chi^{\wedge} 2(12, n=160)$ $=248, \mathrm{p}<.01$. The two ordinal variables (budget for communication and number of people dealing with communication issues in government offices) are strongly positively related to each other, as shown by the gamma value (= $.802, \mathrm{p}<.01$ ) based on the data collected. This means that as the amount of funds planned by municipalities for communication increases, the number of staff dealing with these issues also increases. These findings support hypothesis H4.

The funds earmarked for communications are among other purposes used for the payment of a graphic designer (either hired externally or directly employed by the municipality) to develop and maintain a consistent visual style for the municipality. This one of the important jobs of a graphic designer, as a moderate relationship was found between the two variables, $\chi^{\wedge} 2(2, n=$ $160)=17.34, \mathrm{p}<.01$, Cramer's $\mathrm{V}=.330$.

Our analysis confirmed the logical assumption that the number of communication channels used by municipalities to communicate with their citizens and self-promote is related not only to the size of the budget allocated to the communication strategy of the city (municipality), but also to the type of municipality (I, II, or III). It was found that the results for municipality types I and II were statistically significant $(\beta=$ $3.835, \mathrm{p}<.01)$ and $(\beta=-2.761, \mathrm{p}<.01)$, respectively, and were not significant for the city district of Prague $(\beta=-.622, p=.414$ $>$.1). This implies (as expected) that Type I municipalities will produce (use) 3.835 fewer used communication channels compared to Type III municipalities, or Type II municipalities will use 2.761 fewer communication channels compared to Type III municipalities. The comparison in the number of communication channels between Type III municipalities and urban districts in Prague is not statistically significant. Prague municipalities use on average 3.213 more communication tools than Type I municipalities $(\beta=3.213, \mathrm{p}<.01)$, Type II municipalities use 1.074 more tools than Type I municipalities $(\beta$ $=1.074, \mathrm{p}=.034<.05)$. The regression model confirms what can be intuitively suspected: larger municipalities with not only 
autonomous jurisdiction but also with extended jurisdiction have more options for reaching their citizens through more communication channels than smaller municipalities.

The type of municipality is generally related to the size of the cadastral territory administered by the municipalities or the number of inhabitants living there. How well the dependent variable (=number of communication channels used by the municipality) can be predicted from the independent variable (=number of inhabitants of the municipality in thousands) was investigated using a regression model with this two variables. $18.2 \%$ of the variance of the dependent variable (number of communication channels used by municipalities) can be explained by the variance of the independent variable (number of municipality residents in thousands). In other words, $18.2 \%$ of the variance in the data for the number of communication channels used can be explained by changes in the number of inhabitants of the municipality (the more inhabitants a municipality has, the more communication tools it uses in its daily contact with citizens) $\left(\mathrm{R}^{\wedge} 2\right.$, coefficient of determination $=$ .182). Our data fit a statistically significant regression equation y $=3.803+.034 \mathrm{x}(\mathrm{x}=$ number of inhabitants of the municipality in thousands and $y=$ number of communication channels used); $\mathrm{F}(1,158)=35.138, \mathrm{p}<.01$. This result can be interpreted to mean that municipalities will add one new communication tool to the existing ones in use if the population of the municipality increases by a factor of about thirty (i. e. thirty thousand inhabitants). While our data cannot provide an answer to the question of how well municipalities manage their communication strategy, it does show that larger municipalities reflect the demographic diversity of their citizens and seek to reach them through a more diverse array of appropriate communication channels and, consistent with other research, (Zhang et al., 2021) indirectly confirms that the preferred type of media depends on demographic and personal characteristics.

Tab. 3 presents the results of the regression analysis between the independent variable "region" and the number of communication tools used there. The values in the rows are compared with those of the reference regions (in the columns). It turns out that municipalities in the Zlín Region (compared to other regions) try to communicate with their citizens through a larger number of communication channels. For example, compared to the South Moravian Region, there are on average 3.625 more communication tools used (at the statistical significance level p $=.01$ ). Although the sample of municipalities in the regions is relatively small and not representative, it can be concluded that the Zlín Region as a whole (more than other regions in the Czech Republic) is trying to have a more varied communication strategy and is trying to reach its citizens using a greater number of different communication tools. However, further research is needed to explain this fact.

Tab. 3. The results of regression of region to the number of used communication tools.

\begin{tabular}{|c|c|c|c|c|c|c|c|c|c|c|c|c|}
\hline & 1 & 2 & 3 & 4 & 5 & 6 & 7 & 8 & 9 & 10 & 11 & 1 \\
\hline 1 & & & & & & & & & & & & \\
\hline 2 & $\begin{array}{c}1.1 \\
8\end{array}$ & & & & & & & & & & & \\
\hline 3 & $\begin{array}{l}1.0 \\
8\end{array}$ & .004 & & & & & & & & & & \\
\hline 4 & .03 & 1.04 & .98 & & & & & & & & & \\
\hline 5 &.$\overline{77}$ & .30 & .24 & .74 & & & & & & & & \\
\hline 6 & .30 & .78 & .72 & .27 & .35 & 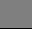 & & & & & & \\
\hline 7 & .56 & .51 & .45 & .53 & .09 & .35 & & & & & & \\
\hline 8 & .36 & .72 & .66 &.$\overline{33}$ & .297 & .14 & .14 & & & & & \\
\hline 9 & $\begin{array}{l}1.7 \\
9^{*}\end{array}$ & $\begin{array}{l}2.86 \\
* *\end{array}$ & $\begin{array}{c}2.80 \\
* *\end{array}$ & $\begin{array}{c}1.8 \\
2\end{array}$ & $\begin{array}{c}2.44 \\
*\end{array}$ & $\begin{array}{c}2.0 \\
0 \\
0\end{array}$ & $\begin{array}{l}2.2 .2 \\
9^{*}\end{array}$ & $\begin{array}{c}2.0 \\
6\end{array}$ & & & & \\
\hline $\begin{array}{l}1 \\
0 \\
\end{array}$ & .25 & 1.33 & 1.27 & .28 & .90 & .46 & .75 & .53 & $\begin{array}{c}1.1 \\
4 \\
\end{array}$ & & & \\
\hline $\begin{array}{l}1 \\
1 \\
\end{array}$ & $\begin{array}{c}1.5 \\
0\end{array}$ & -.42 & -49 & $\begin{array}{c}1.4 \\
7\end{array}$ & -.85 & $\begin{array}{c}1.2 \\
9\end{array}$ & $\begin{array}{c}1.0 \\
0\end{array}$ & $\begin{array}{c}1.2 \\
2\end{array}$ & $\begin{array}{l}2.9 \\
0^{*}\end{array}$ & $\begin{array}{l}1 . \\
67\end{array}$ & & \\
\hline $\begin{array}{l}1 \\
2 \\
2\end{array}$ & $\begin{array}{l}2.5 \\
0^{*}\end{array}$ & $\begin{array}{l}3.58 \\
* * *\end{array}$ & $\begin{array}{c}3.52 \\
* *\end{array}$ & $\begin{array}{l}2.5 \\
3^{*}\end{array}$ & $\begin{array}{c}3.15 \\
n_{* *}\end{array}$ & $\begin{array}{l}2.7 \\
1^{*}\end{array}$ & $\begin{array}{l}3.0 \\
0^{*}\end{array}$ & $\begin{array}{l}2.7 \\
8^{*}\end{array}$ & $\begin{array}{c}1.1 \\
1\end{array}$ & $\begin{array}{l}2.2 \\
33\end{array}$ & $\begin{array}{c}3.63 \\
* *\end{array}$ & \\
\hline$\frac{1}{1}$ & $\begin{array}{c}1.7 \\
5\end{array}$ & $\begin{array}{c}2.83 \\
*\end{array}$ & $\underset{*}{2.77}$ & $\begin{array}{c}1.7 \\
8\end{array}$ & $\begin{array}{c}2.40 \\
*\end{array}$ & $\begin{array}{c}1.9 \\
6 \\
\end{array}$ & $\begin{array}{r}2.22 \\
5 \\
\end{array}$ & $\begin{array}{r}2.0 \\
3 \\
\end{array}$ & .36 & $\begin{array}{c}1 \\
58 \\
58\end{array}$ & $\begin{array}{c}2.88 \\
*\end{array}$ & $\begin{array}{l}.0 \\
8\end{array}$ \\
\hline
\end{tabular}

1-Moravian-slezian region, 2-Region Vysočina, 3-CentralBohemian region, 4-Pardubice region, 5-Liberec region, 6Hradec Králové region, 7-Olomouc region, 8-Ústí region, 9South Moravian region, 10-Plzeň region, 11-South-Bohemian
Region, 12-Zlín region, 13-Prague (capital town); *(p < .05), $* *(\mathrm{p}<.01)$.

Source: own research

From the data collected, further partial conclusions can be drawn, which together form a picture of how municipal (city) authorities operate in the field of communication. Since many of the employees who are involved in communication in selfgovernment offices are not organizationally grouped in the communication department (or in another department specifically focused on the marketing activities of the municipality or city), it can be deduced that they also perform other agenda that may not be related to the municipality's communication. This may reduce the effective use of communication funds, since the employees in charge of communication at the municipality are primarily paid from these funds. It is questionable whether the strong relationship between the communication budget and the number of officials dealing with municipal communication issues is influenced by whether they fall (or do not fall) under a communications department (or a similar specifically focused department within the organizational structure of the government office). Therefore, the relationship between the budget and the number of municipal employees whose agenda is communication was also examined while controlling for another variable: the existence (or not) of a communications department within the organizational structure of the municipality office (which respondents were also asked about). The analysis showed that the gamma value for the "department" category of the control variable $(.999, \mathrm{p}<.01)$ was greater than the gamma value for the "non-department" category of the control variable $(.545, \mathrm{p}<.05)$. From this fact it can be concluded that in terms of the effectiveness of municipal communication, it is desirable for municipalities (if they can afford it) to establish a communications department. Of course, the options that the authority has for staffing and funding its activities are most likely related to the size of the municipality. Thanks to properly chosen communication, invisible public values (opinions, attitudes, preferences) are manifested in the organization. A municipality that actively communicates with the public strengthens its position as a trustworthy institution that is generally perceived as open, welcoming, and transparent; its citizens are more likely to perceive its representatives as looking after the interests of citizens and contributing to the general development of the municipality and increasing its attractiveness. Provided that the municipality has a welldeveloped communication strategy and effectively fulfills its objectives, the credit of the municipality (city) is significantly strengthened both in relation to its citizens and in relation to other actors in the region, a positive media image of the municipality (city, region) is created, the awareness of the locality is increased, and the overall marketing communication of the municipality (city) and the vision contained therein is supported. The communication strategy also aims at building the city's brand and promoting a unified visual style. The results of our study fit in with a growing trend (Canel \& Luoma-aho, 2018) currently visible abroad and characterized by an increase in the range of different activities (not only in the sense of communication), tools used (not only in communication), and examples of good practice in public administration in order to build specific intangible assets.

The results of any empirical study should always be evaluated in light of the chosen research design. Public administration research often relies on unique cases and small samples, which makes it difficult to draw robust conclusions (Van Thiel, 2014). Given the relatively small sample size, the study can be considered more of a research probe that empirically confirms certain intuited assumptions or earlier qualitative findings and suggests a particular direction for further research. Future researchers may look at specific examples of good practice in municipal marketing and qualitatively examine the communication strategies of municipalities (cities) in an attempt to identify their common elements or features and to develop a unified methodology for a communication strategy for municipalities in the Czech Republic. 


\section{Conclusion}

This study demonstrates how a publicly valuable intangible asset is built using the example of communication. A communication strategy is a document that in the medium term defines the principles and procedures of information transfer from the municipality to the citizen, but also vice versa from the citizen to the municipality (city) and can strengthen the participation of citizens to make public decisions. It is a first but essential step towards the active (pragmatic) communication of the municipality, which ceases to be an information provider merely fulfilling its legal obligation. Much more attention is then paid to communication: to self-presentation, to the promotion of the municipality (city) and to reaching different segments of the population through multiple communication channels; a crisis communication plan is prepared, and municipal staff are trained in communication issues. As a rule, the municipality establishes a special department within their offices that is exclusively responsible for the communication agenda, hires a graphic designer to manage the uniform visual style of the municipality (city), and builds the brand of the municipality (city) in a targeted and systematic way. Communication becomes an intangible asset with public value. Municipalities with a welldeveloped and consistently implemented communication strategy serve their citizens and are able to make their locality more attractive, which in turn benefits their inhabitants. Communication can be a means of competitive advantage in the struggle for tourists and investor finance. Unfortunately, this form of competitive advantage is a function of the size of the municipality's cadastral area, or the type of municipality (I, II, and III), and the number of inhabitants living there. Smaller municipalities are at a disadvantage compared to larger ones in this respect and in terms of the funds made available for communication. On the other hand, the results show that it is not only these factors that matter: there are also clear differences in communication activity between the different regions of the country, which relativizes the advantages of large municipalities and suggests that the approach to communication is to some extent an individual matter. In other words, even small municipalities with little financial and human resources can run a quality communication campaign and fight for a competitive advantage in this way.

\section{Literature:}

1. AMI Digital (2021). AMI Digital Index. Praha: AMI Digital. Retrieved November 8, 2021, from https://www.mediar.cz/wpcontent/uploads/2021/06/ami-digital-index_2021.pdf.

2. Bonsón, E., Perea, D., \& Bednárová, M. (2019). Twitter as a tool for citizen engagement: An empirical study of the Andalusian municipalities. Government Information Quarterly, 36(3), 480-489.

3. Bozeman, B., \& Johnson, J. (2015). The political economy of public values: A case for the public sphere and progressive opportunity. The American Review of Public Administration, 45(1), 61-85. http://dx.doi.org/10.1177/0275074014532826.

4. Canel, M., \& García, A. (2013). Communicating trusting governments, Analysis of trust as an intangible asset of the Spanish central government. Zer, 18(34), 29-48.

5. Canel, M. J., \& Luoma-aho, V. (2018). Public sector communication: Closing gaps between citizens and public organizations. John Wiley \& Sons.

6. Canel, M.-J., Luoma-aho, V., \& Barandiarán, X. (2020). Public Sector Communication and Publicly Valuable Intangible Assets. In. N.-J. Canel, \& V. Luoma-aho (Eds.), The Handbook of Public Sector Communication (pp. 101-114). Hoboken (N.J.): John Wiley \& Son.

7. Evstratova, T. A., Kabanova, E. E., Vetrova, E. A., Kulikova, O. A., \& Kolosova, O. A. (2020). The Image of Municipalities. International Journal of Criminology and Sociology, 9, 2711-2717. https://doi.org/10.6000/1929-4409.202 0.09 .335 .

8. Graham, P. (1994). Marketing in the public sector: Inappropriate or merely difficult? Journal of Marketing Management, 10(5), 361-375. http://dx.doi.org/10.1080/02672 57X.1994.9964284.
9. Flatt, S. J., \& Kowalczyk, S. J. (2008). Creating competitive advantage through intangible assets: The direct and indirect effects of corporate culture and reputation. Journal of Competitiveness Studies, 16(1/2), 13.

10. Hallahan, K., Holtzhausen, D., Van Ruler, B., Verčič, D., \& Sriramesh, K. (2007). Defining strategic communication. International Journal of Strategic Communication, 1(1), 3-35. http://dx.doi.org/10.1080/15531180701285244.

11. Hitt, M. P., \& Searles, K. (2018). Media coverage and public approval of the US Supreme Court. Political Communication, 35(4), 566-586. https://doi.org/10.1080/10 584609.2018.1467517.

12. Hoffman, L. H. (2013). When the world outside gets inside your head: The effects of media context on perceptions of public opinion. Communication Research, 40(4), 463-485. http://dx.doi.org/10.1177/0093650211435938.

13. Hong, H., Park, H., Lee, Y., \& Park, J. (2012). Public Segmentation and Government-Public Relationship Building: A Cluster Analysis of Publics in the United States and 19 European Countries. Journal of Public Relations Research, 24(1), 37-68. http://dx.doi.org/10.1080/1062726X.2012.626135.

14. Ježek, J. (2010). Aplikace městského marketingu v praxi: vývoj, očekávání, realita (kritický pohled). E+ M Ekonomie a Management, 10(4), 123-134.

15. Ježek, J. (2011). Městský marketing - koncepty, aplikace, kritická analýza. Ekonomickỳ Časopis (Journal of Economics), 59(3), 243-258.

16. Kaplan, A. M., \& Haenlein, M. (2009). The increasing importance of public marketing: Explanations, applications and limits of marketing within public administration. European Management Journal, 27(3), 197-212. https://doi.org/10.1016/j.emj.2008.10.003.

17. Kawa, A., \& Anholcer, M. (2019). Intangible assets as a source of competitive advantage for logistics service providers. Transport Economics and Logistics, 78, 29-41. https://doi.org /10.26881/etil.2018.78.03.

18. Khan, K. A., \& Hasan, B. (2016). Relationship of acculturative stress with social support, acculturation experience and cultural intelligence: A systematic review. Indian Journal of Health and Wellbeing, 7(1), 67-72.

19. Laing, A. (2003). Marketing in the public sector: Towards a typology of public services. Marketing Theory, 3(4), 427-445. http://dx.doi.org/10.1177/1470593103042005.

20. Liu, B. F., \& Horsley, J. S. (2007). The government communication decision wheel: Toward a public relations model for the public sector. Journal of Public Relations Research, 19(4), 377-393. http://dx.doi.org/10.1080/10627260701402473. 21. Msibi, F., \& Penzhorn, C. (2010). Participatory communication for local government in South Africa: A study of the Kungwini Local Municipality. Information Development, 26(3), 225-236. http://dx.doi.org/10.1177/0266666910376216. 22. Nielsen, J. A., \& Salomonsen, H. H. (2012). Why All This Communication? Explaining Strategic Communication in Danish Local Governments from an Institutional Perspective. Scandinavian Journal of Public Administration, 16(1), 69-89.

23. Potěšil, L., Furek, A., Hejč, D., Chmelík, V., Riegel, F., \& Škop, J. (2019). Zákon o obcích. Praha: C.H.Beck.

24. Ocak, M., \& Findik, D. (2019). The impact of intangible assets and sub-components of intangible assets on sustainable growth and firm value: Evidence from Turkish listed firms. Sustainability, 11(19), 5359. https://doi.org/10.3390/su111953 59.

25. Ochrana, F., Půček, M., \& Špaček, D. (2015). Veřejná správa. Brno: Masarykova Univerzita, Ekonomicko-správní fakulta.

26. Radjenović, T., \& Krstić, B. (2017). Intellectual capital as the source of competitive advantage: The resource-based view. Facta Universitatis, Series: Economics and Organization, 14(2), 127-137. http://dx.doi.org/10.22190/FUEO1702127R.

27. Starosielski, N. (2014). The materiality of media heat. International Journal of Communication, 8(1), 2504-2508.

28. Thoenig, J.-C. (2006). El rescate de la publicness en los estudios de la organización. Gestión y Política Pública, 15(2), 229-258. 
29. Thomas, G. F., \& Stephens, K. J. (2015). An introduction to strategic communication. Los Angeles (CA): Sage Publications. 30. Van Thiel, S. (2014). Research methods in public administration and public management: An introduction. London: Routledge.

31. Zhang, Y., Guo, L., Gil de Zúñiga, H., Xie, T., \& Zhang, R.

J. (2021). Demographic inequalities or personality differences? Exploring six types of social media usage divides in Mainland China. The Social Science Journal, 1-17. https://doi.org/10.1080/03623319.2020.1851952.

\section{Primary Paper Section: A}

Secondary Paper Section: AE, AJ, AP 